\title{
A case of endocrinologic crisis in a woman with subacute blindness
}
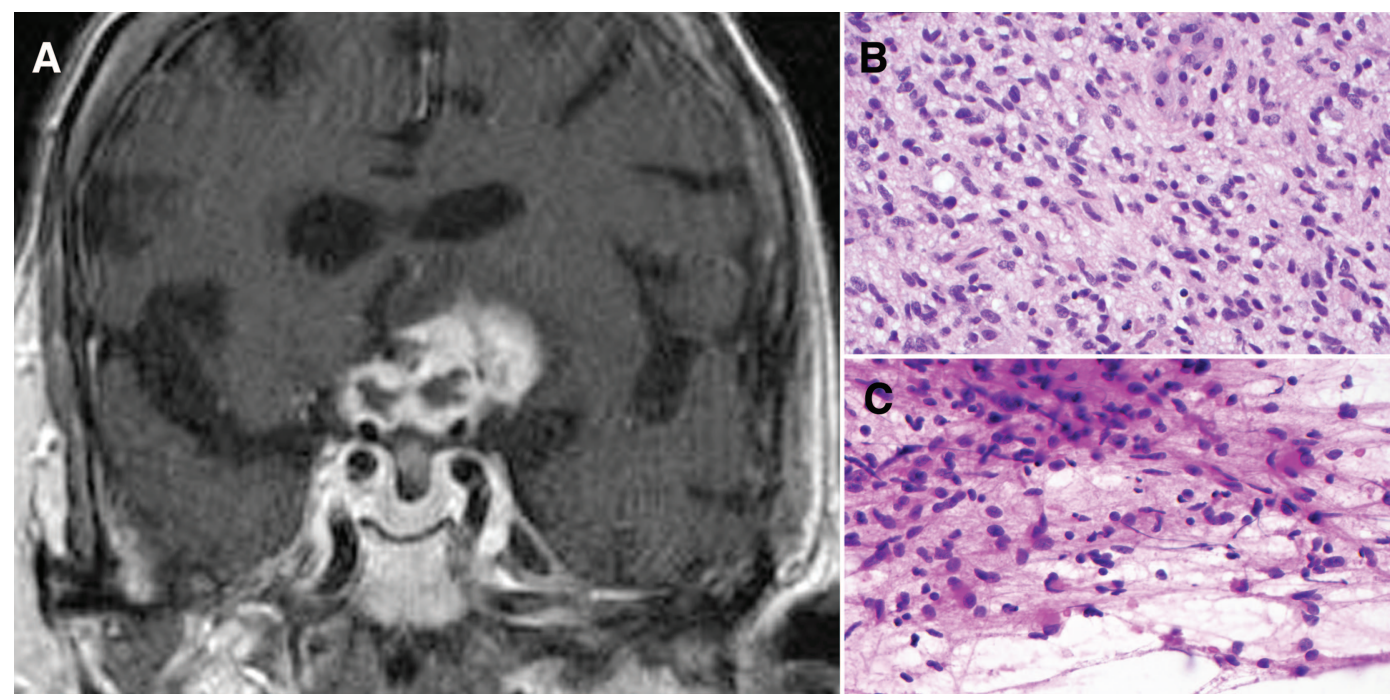

(A) Coronal T1 postgadolinium MRI showing heterogeneously enhancing mass centered within the suprasellar cistern involving the optic apparatus and hypothalamus extending superiorly to involve the inferior frontal lobes. (B, C) Biopsy specimen histologic section shows hypercellular fibrillary malignant neoplasm with moderate cytologic atypia and rare apoptotic bodies (hematoxylin-eosin stain, $400 \times$ original magnification).

A

79-year-old woman presented to our emergency department with subacute, sequential, severe optic neuropathies and encephalopathy. She had been treated for suspected giant cell arteritis at an outside facility several months earlier (elevated erythrocyte sedimentation rate and minimal left optic nerve enhancement). On our evaluation she had panhypopituitarism and a large, gadolinium-enhancing optic apparatus mass extending through the hypothalamus and into the frontal lobes (figure, A). Biopsy diagnosed grade IV fibrillary astrocytoma (glioblastoma multiforme; figure, B and C). Optic nerve gliomas are typically lowgrade and diagnosed in childhood, while rare adult cases are often high-grade glioblastoma as in the present case. ${ }^{1,2}$

Tamika M. Burrus, MD, Matthew T. Drake, MD, PhD, Schuyler O. Sanderson, MD, B. Mark Keegan, $M D$, FRCP(C)

From the Departments of Neurology (T.M.B., B.M.K.), Medicine (M.T.D.), and Laboratory Medicine and Pathology (S.O.S.), Mayo Clinic, Rochester, MN.

Disclosure: Dr. Burrus reports no disclosures. Dr. Drake receives research support from the NIH (NCI 2R01 CA 107476-6 [coinvestigator] and NIA P01 AG 004875 [coinvestigator]. Dr. Sanderson reports no disclosures. Dr. Keegan serves as a Section Editor for Neurology ${ }^{\circledR}$ and as Chief Editor of eMedicine and has served as a consultant for Novartis.

Address correspondence and reprint requests to Dr. B. Mark Keegan, Department of Neurology, Mayo Clinic, 200 1st Street SW, Rochester, MN 55905; keegan.bmark@mayo.edu

Received February 11, 2010. Accepted in final form September 1, 2010.

1. Hoyt WF, Mesehel LG, Lessel S, Schatz NJ, Suckling RD. Malignant optic glioma of adulthood. Brain 1973;96:121-132.

2. Dinh TT, Wang YY, Rosenfeld JV, Cherny M. Glioblastoma of the optic chiasm. J Clin Neurosci 2007;14:502-505. 


\section{Neurology}

\section{A case of endocrinologic crisis in a woman with subacute blindness \\ Tamika M. Burrus, Matthew T. Drake, Schuyler O. Sanderson, et al. \\ Neurology 2010;75;S65 \\ DOI 10.1212/WNL.0b013e3181fb35c6}

\section{This information is current as of November 1,2010}

\section{Updated Information \&}

Services

References

Subspecialty Collections

Permissions \& Licensing

Reprints including high resolution figures, can be found at: http://n.neurology.org/content/75/18_Supplement_1/S65.full

This article cites 2 articles, 0 of which you can access for free at: http://n.neurology.org/content/75/18_Supplement_1/S65.full\#ref-list-1

This article, along with others on similar topics, appears in the following collection(s):

All Clinical Neurology

http://n.neurology.org/cgi/collection/all_clinical_neurology All Neuro-ophthalmology

http://n.neurology.org/cgi/collection/all_neuroophthalmology Electrolyte

http://n.neurology.org/cgi/collection/electrolyte

MRI

http://n.neurology.org/cgi/collection/mri

Primary brain tumor

http://n.neurology.org/cgi/collection/primary_brain_tumor

Information about reproducing this article in parts (figures,tables) or in its entirety can be found online at:

http://www.neurology.org/about/about_the_journal\#permissions

Information about ordering reprints can be found online:

http://n.neurology.org/subscribers/advertise

Neurology ${ }^{\circledR}$ is the official journal of the American Academy of Neurology. Published continuously since 1951, it is now a weekly with 48 issues per year. Copyright Copyright $@ 2010$ by AAN Enterprises, Inc.. All rights reserved. Print ISSN: 0028-3878. Online ISSN: 1526-632X.

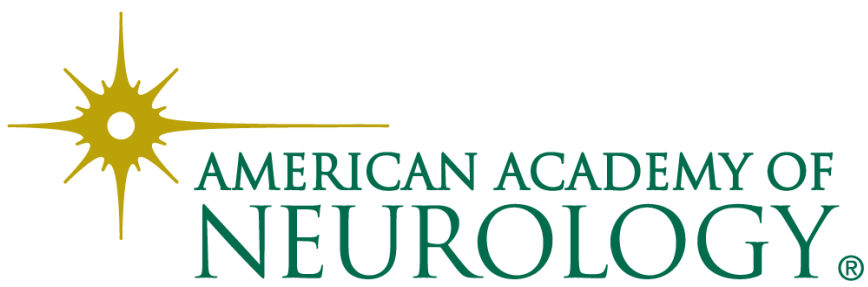

